doi: $10.19090 /$ i.2019.30.234-255

UDC: 94(497.1)“1929/1935“"

ISTRAŽIVANJA

JOURNAL OF HISTORICAL RESEARCHES

$30(2019)$
ORIGINAL SCIENTIFIC PAPER

Received: 22 November 2018

Accepted: 1 July 2019

VASILIJE DRAGOSAVLJEVIĆ

The Institute of History, Belgrade

v.dragosavljevic@yahoo.com

\title{
ASSOCIATION OF FIGHTERS OF YUGOSLAVIA (1929-1935): IDEOLOGY - PRACTICE - OUTCOME
}

\begin{abstract}
The paper aims to present the process of creation, i.e. organizational and ideological shaping of the veteran movement of the Association of Fighters of Yugoslavia (AFY, Serbian BOJ) and illuminate its role in the context of Yugoslav integrationist forces in the first half of the 1930s. A special focus will be placed on the adoption of ideological constructions of the Organization of Yugoslav Nationalists and contemporary French veteran movements. The paper also sheds light on the complex relations between AFY, the 6 January regime and contemporary, ideologically related political groups, and on the role of ideological conceptions of AFY in the creation of the ideology of the Yugoslav National Movement Zbor.

Keywords: Association of Fighters of Yugoslavia, Organization of Yugoslav Nationalists, integrationist Yugoslavism, clericalism, Yugoslav National Movement (YNM) Zbor.
\end{abstract}

$\mathrm{U}$ pon its inception in 1929 the Association of Fighters of Yugoslavia (AFY, Serbian BOJ) was at first sight one of many veteran/patriotic non-political organizations established after the 6 January Manifesto in order to back the monarchical dictatorship regime and ensure support among the wider population. In contrast to the majority of these organizations, during its existence (1929-1935) and relying on the membership and ideological legacy of the Organization of Yugoslav Nationalists (OYN, Serbian ORJUNA), AFY managed to build a strong organizational structure, broaden its membership base and shape, to a greater or lesser extent, its ideological construct, connect itself with ideologically similar political groups and thus expand its influence outside the borders of the Drava Banovina (Slovenia). At its inception the movement did not have a clear-cut and definitive ideology, relying instead on the vague vision of a totalitarian state without the participation of parties and with a strong nationalistic note embodied in the ideology of integrationist Yugoslavism, which King Aleksandar tried to bring to fruition during the monarchical dictatorship. Starting from these bases, in the course of 1929-1935 AFY's ideology was slowly gaining increasingly defined contours. A significant role in this long-lasting process was played by the ideological heritage of OYN and the ideological conceptions of contemporary French veteran movements manifested in the adoption of some ideological precepts of the Young Patriots, Cross of Fire and French Solidarity. 


\section{Ideological legacy of the Organization of Yugoslav Nationalists}

Founded on avant-garde political theories and adoption of extremist ideas and methods, $\mathrm{OYN}^{1}$ was a specificum of the political scene of the Kingdom of Serbs, Croats and Slovenes (SCS). The ideological grounding of this extra-parliamentary political organization, active throughout the 1920s in the entire territory of the Kingdom of Yugoslavia, was the theory of integrationist Yugoslavism - a form of the Yugoslav idea which rejected any ethnic, state, legal and cultural specificities of the Yugoslav peoples and advocated a centralized government. The idea was outlined in the late $19^{\text {th }}$ and early $20^{\text {th }}$ century by Svetozar Pribićević, ${ }^{2}$ Jovan Skerlić ${ }^{3}$ and Jovan Cvijić, ${ }^{4}$ but the main contribution to its development into an ideological system came from the political thinkers from OYN. Aiming to provide a rational backing to this theory, the main ideologists of OYN Prvislav Grisogono ${ }^{5}$ and Franjo Malin ${ }^{6}$ created a number of paradoxical historical constructions aimed at proving the existence of a single Yugoslav people. Putting on a pedestal the principle of national and state unitarism, the OYN ideologists set as the ultimate objective the unification of the Yugoslav peoples within a single state, which in practice engendered an aggressive foreign policy agenda embodied in the concept of Greater Yugoslavia stretching from Trieste to Varna and from Szeged to Thessaloniki. ${ }^{7}$ In addition to these autochthonous designs, OYN's ideological construct was largely shaped by the ideological tenets (and political practice) of Italian fascism from which the model of a corporate state and a systemic use of terror in confronting political opponents was adopted. By mid 1920s OYN established its organizations in the entire territory of the Kingdom of SCS (the figure of over 100,000 members was hypothesized), numerous border committees, and an armed and trained party militia of 10,000 fighters. ${ }^{8}$ The aggressive rhetoric of its leaders and brutal incidents of its activists until mid 1920s pushed this organization to the margins of political life, while at the same time leaving an ideological legacy which would underpin all political organizations of the Yugoslav right-wing during the 1930s and 1940s.

\subsection{Disintegration of OYN - creation of AFY}

The creation and the process of ideological construction of AFY were inextricably linked to OYN's disintegration. After the introduction of the monarchical dictatorship in 1929, members of the dissolved OYN in Slovenia led by the great head ("veliki čelnik") Marko Kranjec ${ }^{9}$ continued with their political work, heedless of the Yugoslav authorities'

1 For more information about the history and ideology of OYN see: Bartulović 1925, Bošković 2006, Gligorijević 1963b, Gligorijević 1986, Dragosavljević 2015, Dragosavljević 2018: 61-246, Devavari 2017, Djordjević 2006, Djurasević 2007, Avakumović 1971: 135-143, Šuštar 1989, 1989 b.

Pribićević 2000: 123-136; Matković 1972: 85-88.

Bakić 2004: 133-134; Ković 2015: 536-539.

Cvijić 1999.

Grisogono 1923.

Malin 1925.

Djordjević 2006: 211-212.

Gligorijević 1963b: 337, 339.

He was born on 12 November 1885 in Ilirska Bistrica. He graduated from a chemistry faculty at the Vienna University. In World War I, he was recruited to the army of the Habsburg Monarchy. In early 1917, he fled to 
ban on the movement. During the following two years, Slovenian OYN members focused their efforts on the organization and implementation of subversive activities in the territory of Italy..$^{10}$ According to data of the Italian intelligence service, former OYN members collectively joined the National Defence and under the veil of the new organization continued their work against Italy. ${ }^{11}$ The fact that the former leader of Ljubljana OYN dr Josip Cepuder became the head of the county board of the National Defence for the Drava Banovina (Slovenia) confirms this observation of the Italian intelligence service. ${ }^{12}$ In early 1930 OYN members from Slovenia led by Marko Kranjec connected themselves with the membership of the centre of the Italian anti-fascist emigration in Paris for the purpose of a joint struggle against the fascist regime in Italy. These political emigrants were mainly members of the Communist Party of Italy, which is why the Yugoslav authorities became wary that former OYN members would come under the influence of leftist ideas. These suspicions motivated the Yugoslav authorities to transfer Kranjec as the main activist in the implementation of the irredentist actions from the customs service in Slovenia first to Skopje and then to Niš. ${ }^{13}$ After Kranjec left Slovenia in October 1930, the OYN units that carried out terrorist actions in the Italian territory were reorganized within the Maritime Propaganda Board. These units were headed by the retired general Rudolf Maister, who excelled in the Yugoslav-Austrian war around Styria and Carinthia in 1918-1919. In 1929, the initiative for the creation of the political organization of Slovenian warriors-veterans from World War I arose from the ranks of Maister's units. In late 1929, with the engagement of the former members of the Yugoslav Nationalist Youth and OYN - Vladislav Vlatko Fabijančić, ${ }^{14}$ Avgust Kuster and Stane

the Italian army. A separate military formation, the so-called Pivko's battalion, was formed out of Slovenian and Croatian deserters, which fought on the side of the Italian army against Austria-Hungary. During the last year of the war Kranjec fought within this formation. In 1922, Kranjec joined OYN as the head of the county board in Ljubljana. In 1926-1929 he was the great head ("veliki čelnik") - the commander in chief of the Action Units. In addition to his official duties in OYN, Kranjec led a secret action of the organization and coordination of work of irredentist Yugoslav associations TIGER, OYN and Fantovska zveza in the territory of Italy and Austria. Upon the dissolution of OYN in 1929, with a group of former OYN members, Kranjec continued with the activities of irredentist terrorist and military-intelligence character in Italy. In the early 1930 s, Kranjec played an important role in the efforts to restore the work of OYN and eventually joined the Yugoslav Action (Bartulović 1925: 70, 101; Gligorijević 1963b: 335, 390).

10 ARS, SI AS 1931, 935-600-12, document: Materijal goričke kvesture o Orjuni (report dated 25. 1. 1929).

11 ARS, SI AS 1931, 935-600-12, document: Materijal goričke kvesture o Orjuni (report dated 26. 1. 1929).

12 ARS, SI AS 1931, 935-600-12, document: Elaborat o ORJUNI.

13 ARS, SI AS 1931, 935-600-12, document: Materijal goričke kvesture o Orjuni (report dated 10. 8. 1936).

14 An eminent member of the pre-war Yugoslav Revolutionary Youth and editor of the youth magazine Preporod from Ljubljana. In July 1913, due to his pro-Yugoslav attitudes expressed in Preporod, he was arrested by the Austrian authorities. As a volunteer, Fabijančić joined the Serbian army and took part in the battle on Cer. During the war years he participated in the creation of the Yugoslav Board in Niš and its work in Rome. He participated in the formation of the so-called Pivko's battalion - a military formation consisting of Slovenian and Croatian deserters from the Austro-Hungarian army, who fought on the side of Italy against AustriaHungary. After World War I he joined the socialist movement in Slovenia and took part in the Vukovar Congress and formation of the Communist Party of Yugoslavia (CPY). As he espoused the attitude that CPY should cooperate with Slovenian social-democrats, in April 1923 Fabijančić was excluded from the Party. In 1925-1928 he was the president of Zveza vojnih dobrovoljcev (Union of Military Volunteers) in the Serbian army. Upon the introduction of the monarchical dictatorship in 1929, Fabijančić - together with his former comrades from the Yugoslav Revolutionary Youth and Pivko's battalion Stane Vidmar and Avgust Kuster, as 
Vidmar ${ }^{15}$, the organization Zveza slovenskih vojakov (Union of Slovene Soldiers) was set up, gathering the Slovenians who during World War I fought as volunteers in the army of the Kingdom of Serbia. Several months later, in 1930, the organization changed its name into Zveza bojevnikov (Union of Soldiers), opening its door also to all Slovenians who did the military service in the Kingdom of SCS. Retired general Rudolf Maister was elected head of the organization. The movement was managed by the Central Board which included, in addition to Fabijančić, Kuster and Vidmar, the representatives of the National Defence, Association of Reserve Officers, Association of War Invalids and Association of Četniks for the Drava Banovina. ${ }^{16}$ Aiming to preserve the semblance of a non-political organization, the leadership of Zveza bojevnikov emphasized as its main objectives the care about the social status of veterans and the promotion of the idea of state and national unity. During the first years of its existence, the movement was under the auspices of the regime Yugoslav National Party (YNP). Numerous former members of OYN and the ideologically close Independent Democratic Party (IDP) ${ }^{17}$ in the area of Slovenia joined the ranks of the regime YNP and

well as the leader of the Slovenian forces from the war in Carinthia Rudolf Maister - established Zveza slovenskih bojevnikov (Union of Slovenian Soldiers). After King Aleksandar was assassinated in Marseille in October 1934, together with Parežanin and Ljotić, Fabijančić initiated the unification of Yugoslav integrationist organizations - AFY, Yugoslav Action, Small Zbor and Otadžbina group into the Yugoslav National Movement (YNM) Zbor. At the parliamentary elections in 1935, Fabijančić was a candidate on the YNM Zbor list in the Krško and Ptuj county. After YNM Zbor failed in the elections, in 1935 Fabijančić became politically passive (Anonym, Naši predniki: Preporodovci 1914-1934, Prelom yr I No 11, 29 March 1934; Vladislav Fabijančić, Dvajesletnica cerske bitke, Prelom yr I No 32, 23. 8. 1934; Ekmečić 1989: 540541; Gligorijević 1992: 68,70,102,104,190; Bartulović 1925:77; Gligorijević 1965: 59-61; Parežanin 2001: 47-49, 54, 144; AB, Fund of Ljotić's organization Zbor, box no.6, document: National Candidate List for the elections of deputies for the National Assembly on May 5, 1935.

15 A prominent member of the pre-war Yugoslav Nationalistic Youth in Slovenia. After the outbreak of World War I, he was first arrested by the Austrian authorities as a Yugoslav nationalist and was then mobilized and sent to the Italian front. In early 1917 he fled to the Italian army and joined the so-called Pivko's battalion which fought on the side of the Italian army against Austria-Hungary. In 1929, together with Avgust Kuster and Vladislav Fabijančić, he established the veteran association Zveza slovenskih vojakov (as of 1933 known as the Association of Fighters of Yugoslavia - AFY). Although Ratko Parežanin, in his work World War II and Dimitrije V. Ljotić, considers him one of the initiators of a closer cooperation of Yugoslav integrationist movements of the radical right-wing, during the preparations for the campaign in the parliamentary elections in 1935 Vidmar was a decisive opponent of AFY's participation in National Candidate List for the elections of Dimitrije Ljotić. Such Vidmar's attitude brought about a rift within AFY and significantly contributed to the poor result of the National Candidate List for the elections of D. Ljotić in the Drava Banovina. According to B. Gligorijević, on the eve of the parliamentary elections in 1935, Vidmar, together with his political supporters, left AFY and continued his political work in terms of struggle for the political autonomy of Slovenia within the Kingdom of Yugoslavia (Parežanin 2001: 27-28, 42, 44, 47-48; Gligorijević 1965: 73-77).

16 During the 1920s, all these organizations cooperated closely with OYN (Gligorijević 1963b: 347, 364).

17 The membership of OYN and IDP shared the faith in the theory of integrationist Yugoslavism. The IDP leader Svetozar Pribićević was one of the architects of this political idea. Although OYN defined itself as a supraparty movement (as well as an anti-party movement given the advocation of a corporate state model), in all electoral processes in 1921-1927 it was supporting the campaign of IDP as the only parliamentary political party which, in accordance with the theory of integrationist Yugoslavism, espoused uncompromising national and state unitarism. In the historiography of the socialist period there are even the theses according to which OYN was a party militia, i.e. the extremist wing of IDP. These theses, however, are not true because, despite the ideological closeness of the two organizations, there were frequent discords and conflicts. After S. Pribićević made a coalition with the Croatian Peasant Party in 1927 and gave up on the policy of unitarism 
took high positions in the state administration. The leader of the Slovenian IDP Albert Kramer became the secretary general of YNP and the head of his cabinet was a former OYN member (the main assistant of Marko Kranjec) Anton Verbič. With Verbič's support, Drago Marušič ${ }^{18}$, a former OYN member and now the Ban of the Drava Banovina, helped the gathering and political work of his former comrades within Zveza bojevnikov. Under the auspices of the regime YNP, Zveza bojevnikov established a number of local boards across the Drava Banovina. In addition to former OYN members, members of the dissolved parties which espoused the ideology of integrationist Yugoslavism also joined the movement - those were primarily the former members of the IDP and the Slovenian Agricultural Party (SAP), as well as pro-Yugoslav members of the dissolved clerical Slovenian People's Party (SPP). In the second half of 1933, Zveza bojevnikov organized several well-attended rallies across the Drava Banovina with speakers emphasizing the movement's commitment to the ideas of the 6 January Manifesto and criticizing the work of the dissolved parties. The broadening of the membership base of Zveza bojevnikov in 1932 and 1933 stirred the ambitions of the regime YNP and the dissolved SLS to place the movement under their control. A conflict arose within the Slovenian YNP branch among members of the dissolved IDP (Albert Kramer and Podban Pirkmajer) and SAP (Ban Marušič) as to who would ensure the support of Zveza bojevnikov to the regime. ${ }^{19}$ In the context of these conflicts, in 1933 Pirkmajer banned Zveza bojevnikov, but with the victory of Marušič in the internal strifes in YNP, the movement restored its work in December 1933 under the name Združenje borcev Jugoslavije - BOJ (the Association of Fighters of Yugoslavia, AFY). Under the patronage of Ban Drago Marušič, the restored movement left the positions of a non-political veteran association and, under the leadership of Fabijančić, Kuster and Vidmar, began to form its political programme and ideology.

\subsection{Integrationist Yugoslavism}

The presence of a great number of former OYN members among the members and

and centralism, the cooperation between OYN and IDP came to an end.

18 Born in 1884 in Opatje selo in Gorica. Graduated from the Law Faculty in Prague in 1911. After the studies, he worked as a lawyer and secretary of the Slovenian National Party in Gorica. According to data presented by Bartulović, Marušič was one of the rare politicians who helped the work of the Yugoslav Nationalistic Youth in Slovenia in the period before 1914. In World War I he deserted from the Austrian army and from 1915 fought as a volunteer in the army of the Kingdom of Serbia. During the war he also got engaged as a member of the Yugoslav Board. After the war he worked as a lawyer and joined the Independent Agricultural Party and the Slovenian Cooperative Movement. In the 1920s, he joined OYN and in 1924 was elected the president of Economic OYN. In early 1929, Marušič sided with the 6 January regime and in 1930-1935, as a member of the Yugoslav National Party, served as the Ban of the Drava Banovina. In this period, he was the main supporter of AFY. As a representative of AFY and the Slovenian Cooperative Movement, in 1935 he stood as a candidate in the list of B. Jevtić and was elected an MP. In the April war of 1941 Marušič participated in the struggles on the front towards Italy as a volunteer. After the war he got engaged in the Liberation Front of Slovenia, which is why he was arrested by the Italian authorities and interned in Padua. After the capitulation of Italy, he came to the Slovenian littoral and got engaged in the People's Liberation War. After the Tito-Šubašić agreement, he was appointed a minister in the Yugoslav Government in London. Until 1948 he served as the Minister of Post and Telegraph in the Government of the Democratic Federal Yugoslavia. He died in 1964 in Gorica (Antoličić 2016: 195-196, 197; Čop 2006: 76-77; Gligorijević 1965: 60-61). ASAF, Inventory No 17, box No 95, folder No 1, document No 1. 
leaders of AFY brought about the absorption of many ideological conceptions of OYN within the ideology of the new movement. Firstly, AFY adopted the OYN theory of integrationist Yugoslavism. Just like OYN members, the ideologists of AFY presented themselves as the successors of political work of the pre-war Yugoslav Nationalistic Youth (YNY). The tendency of presenting AFY as the political successor of YNY is the most evident in the articles such as Our Predecessors of Preporod 1914-1934, ${ }^{20}$ Speech of Stane Vidmar, ${ }^{21}$ and The Twentieth Anniversary of the Battle of Cer. ${ }^{22}$ The authors of these articles praised the work of the Slovenian youth gathered around the Ljubljana paper Preporod, who after the Balkan Wars joined the Yugoslav Nationalistic Youth. Particularly emphasized was the role of Vladislav Fabijančić (one of founders of AFY) in connecting the pro-Yugoslav Slovenian youth with like-minded persons in Croatia, Dalmatia and Bosnia and his volunteer service in the army of the Kingdom of Serbia. Based on the ideas presented in the articles such as The Twentieth Anniversary, ${ }^{23}$ Fatal Shift ${ }^{24}$ and Where to ${ }^{25}$, it can be inferred that - both for OYN and AFY members - World War I had the character of a national revolution, where the idea of Yugoslavism, through the struggle and sacrifice of JNO members and feats of the army of the Kingdom of Serbia, triumphed over the anachronistic ideas of Habsburg feudalism and nationalisms of Yugoslav tribes. Unlike OYN, which due to the specific political circumstances promoted the idea of integrationist Yugoslavism from the positions of the political margins and intellectual avant-garde, the ideologists of AFY approached the same task from a much more comfortable position where this idea was shaped into the axiom of state policy. Therefore, the gazettes of AFY practically do not contain articles which, by means of historical constructions, idealize the past of a single Yugoslav people. An exception was the article Karađorde, the First Champion of a Free Yugoslavia ${ }^{26}$ where an anonymous author presented the leader of the First Serbian Uprising and forefather of the Karađorđević dynasty as a political visionary who in the early $19^{\text {th }}$ century led the Serbian people into the struggle for the creation of the Yugoslav state. This more comfortable position enabled the AFY ideologists to embrace a more rational view of the existence of a single Yugoslav people. Unlike the ideologists of OYN who treated each manifestation of tribe individualism as a blasphemous deviation from the theory of integrationist Yugoslavism, the ideologists of AFY believed that each tribe of the Yugoslav people had its specific role in the Yugoslav synthesis, which is why it was not constructive to negate the cultural identities of the Serbian, Croatian and Slovenian tribe/people. ${ }^{27}$ The ideologists of AFY adopted OYN's ideological premise according to which the Croatian tribe politically shaped the idea of Yugoslavism, while the Serbian tribe contributed with its forces to its materialization. ${ }^{28}$ The destructive politics of the pre- 6 January parties triggered

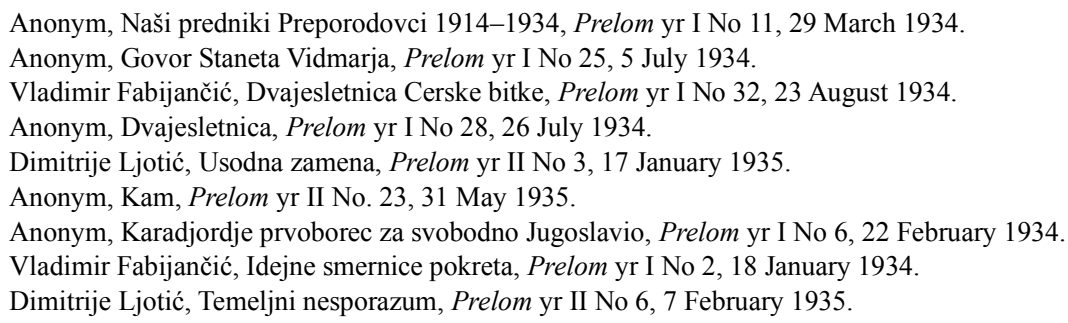


a conflict between the Serbian and Croatian tribes, creating an atmosphere where the Yugoslav question was simplistically degraded to the issue of an agreement between the Serbs and the Croats, where the Slovenians were a marginal factor, with a malicious tendency of the assimilation of the Slovenian tribe by the Croats. ${ }^{29}$ Contrary to this unenviable position of the Slovenian tribe, the ideologists of AFY believed that the Slovenians, as "the most prominent point of Slavism" towards Germany and Italy (and therefore more conscious of the danger threatening Yugoslavia) ${ }^{30}$ were destined to become "the Yugoslav Sparta" 31 , i.e. to take over from the Croatian and Serbian tribes the leadership in the struggle for the achievement of the idea of integrationist Yugoslavism. ${ }^{32}$ Despite this rationalistic approach to the theory of integrationist Yugoslavism, the ideologists of AFY were not less aggressive in their promotion than their predecessors from OYN and contemporaries from the Yugoslav Action. In their gazettes, the ideologists of AFY labelled "the tribal separatists" (followers of the pre-6 January parties) as "Judas Iscariot", 33 their leadership as "the merchants in the Lord's temple" (whom the King, by means of the 6 January act, permanently eliminated from the political life of Yugoslavia) ${ }^{34}$, emphasizing that the idea of state and national unity expressed in the 6 January Manifesto was the "Gospel of AFY". ${ }^{35}$ The joint activity of AFY with other rightist political groups of integrationist Yugoslav orientation (the Yugoslav Action, ${ }^{36}$ Small Zbor (Mali Zbor) ${ }^{37}$ and political groups gathered around the papers Buđenje ${ }^{38}$ and Otadžbina ${ }^{39}$ ) in the list of Dimitrije Ljotic at the parliamentary elections in 1935 was characterized by the AFY leadership as the triumph of the Yugoslav idea. According to the anonymous author of the article Dimitrije Ljotic in Slovenia ${ }^{40}$ by joining the forces of integrationist Yugoslavism, AFY left the political isolation ("We are no longer lonely in the Slovenian corner of Yugoslavia") and, bolstered by the followers from the Croatian and Serbian tribes, entered

\footnotetext{
Anonym, Ne tako, Prelom yr II No 31, 31 August 1935.

Anonym, Govor tovariša Tureta Šturma, Prelom yr I No 14, 19 April 1934.

Anonym, Celjski zbor, Prelom yr I No 18, 17 May 1934.

Anonym, 1935 leto naše besede, Prelom yr I No 50, 27 December 1934.

Vladimir Fabijančić, Idejne smernice pokreta, Prelom yr I No 2, 18 January 1934.

Anonym, Govor tovariša Tureta Šturma, Prelom yr I No 14, 19 April 1934.

Anonym, Izjava tovariša Kruleja na seji JNS, Prelom yr I No 4, 8 February 1934.

3 The Yugoslav Action was created during the attempts to restore the work of OYN in 1929-1930. The nucleus of this political group consisted of former senior OYN officials such as Marko Kranjec, Ilija Čavlin, Aleksandar Stulhofer and Čedomilj Medini. It attracted the major part of the membership of former OYN from Croatia, Dalmatia and Slovenia. In this regard, the new organization embraced a large portion of the ideological legacy of OYN, including parts of the ideological discourse of Italian fascism (the new man concept) and German national-socialism (the glorification of the peasantry) (Dragosavljević 2018: 264-311, Gligorijević 1965, Payne 1995: 325-326).

37 A small political group created in 1933 and gathered around the Zbor paper and radical dissident Ratko Parežanin (Parežanin 2001: 22-24).

38 A small political group created in 1933 with the seat in Banat and gathered around radical dissident Milorad Mojić and the Buđenje paper (Parežanin 2001: 35, 41).

39 After serving as the Minister of Justice over less than a year in the government of Petar Živković, in 1932 radical dissident Dimitrije Ljotić began to create his own political organization. During 1932-1934 this group functioned as a close circle. With the establishment of the Otadžbina paper in 1934, this group began to present its ideas to the Yugoslav public (Parežanin 2001: 34-36).

40 Anonym, Dimitrije Ljotić u Sloveniji, Prelom yr II No 16. 18 April 1935.
} 
the decisive phase of struggle for the achievement of its political programme.

\subsection{Expansionism}

In the context of the adoption of the OYN theory of integrationist Yugoslavism, the ideologists of AFY also embraced the expansionary foreign policy plans of OYN. In his speech held at the gathering of bojevniks in Ljubljana on 8 January 1934, Vladislav Fabijančić presented AFY's foreign policy programme as follows: "The fighters' association of Yugoslavia wants Yugoslavia to become a powerful, great force, under the sceptre of the national dynasty of Karađorđevićs, which would in brotherly coexistence bring together all Slovenians, Serbs and Croats. It aims to join and bring together the entire Slavic south in freedom, from the farthest borders where the Slovenians live up to the Slavic Black Sea." ${ }^{41}$ Based on these words of the most prominent leader of AFY, it is possible to conclude that AFY assumed from OYN the idea of the creation of Greater Yugoslavia stretching from Trieste to Varna. As AFY was created primarily as an organization of the Slavic tribe of the Yugoslav people, its ideologists, in terms of foreign policy issues, devoted most attention to Carinthia - the Austrian province where a large number of ethnic Slovenians lived. In the articles such as On the Occasion of the Jubilee of General Maister ${ }^{42}$ The Association of the Fighters of Yugoslavia in Dolenjska Metropola ${ }^{43}$ Memento $^{44}$ and General Maister ${ }^{45}$, the ideologists of AFY reminded the public of the undeclared war that Yugoslav volunteers led with the Austrian Heimwehr around Carinthia in 1918-1919. The authors of articles emphasized the heroism and sacrifice of Yugoslav volunteer corps led by general Rudolf Maister (the honorary president of AFY) and the unjust policy of the European forces which allocated Carinthia to Austria. The author of the article German Colonization in Carinthia ${ }^{46}$ warned the Yugoslav public that the Austrian authorities in Carinthia carried out a sweeping project of the colonization of this province with the German population so that this province would lose any trace of its Slavic character. The author emphasized that the Yugoslav state had to oppose these intentions of the Austrian authorities as otherwise the Slovenian territories in the Kingdom of Yugoslavia would also be jeopardized. Upon the model of dissolved OYN, the leadership of AFY tried to establish its own party militia called guard units ("redarski odredi"). The leadership of AFY conceived this idea in early May $1934 .{ }^{47}$ The concrete reason for the creation of guard units were the incidents and provocations of communists and members of the dissolved SLS at the rallies of AFY. In the archival records there is no mention of the actions of guard units, but their presence is noted at several rallies held by AFY in Slovenia during the summer of 1934. According to a photograph published in Prelom of 24 May 1934, it is possible to

\footnotetext{
AY, fund No 38 folder No 4, Report of the CPB of the AFY Meeting in Ljubljana on 8 January 1934.

Anonym, Ob jubileju generala Maistra, Prelom yr I No 12, 5 April 1934.

Anonym, Združenje borcev Jugoslavije v dolenjski metropoli, Prelom yr I No 13, 12 April 1934.

Anonym, Memento, Prelom yr I No 21, 7 June 1934.

Anonym, General Majster, Prelom yr I No 29, 2 August 1934.

Anonym, Nemeška kolonizacija na Koroškem, Prelom yr II No. 13, 28 March 1935.

The announcement of the gathering of soldiers in Celje on the first page of the Prelom paper of 10 May 1934 (yr I No. 17).
} 
conclude that the guard units carried olive-grey uniforms and had special cavalry troops. ${ }^{48}$

\section{Ideological influences of French veteran movements}

\subsection{French veteran movements}

After World War I, the reputation of the French army was at its highest. Society at large celebrated members of the armed forces and paid due respect to the killed and injured soldiers, establishing the cult of victory and courage of French soldiers. ${ }^{49}$ At the forefront of creating this cult was the French Action (Action Française) $)^{50}$, a neoroyalist movement which since its inception in the Dreyfus Affair imposed itself as the protector and apologist of the army and which, during the war years, stood out in its relentless propaganda against the defeatists, German spies and all political elements who brought into question the victory of the French arms. ${ }^{51}$ In the first half of the 1920 s French veterans were mainly passive in respect of current political circumstances, not feeling the need to act as an organized political group. The exception was the creation of the veteran association Civic Union in 1920 as a response of former soldiers to a series of strikes instigated by trade unions under the control of the Socialist Party. The Civic Union was an apolitical association of former soldiers which fostered the cult of victory and provided support to state services whose functioning was jeopardized by strikers' activities. ${ }^{52}$ Workers' strikes, the lenient policy of the Cartel of the Left towards the strikers and the ceremonial funeral of the leader of the Socialist Party Jean Jaurès, which the communists turned into grand anti-war demonstrations, caused a lot of disturbance among French veterans, who interpreted these events as a new ascent of Germany ${ }^{53}$ and a great danger for the results of the victory of the French army. ${ }^{54}$

The communist demonstrations at the funeral of Jean Jaurès in November 1924 inspired war hero Pierre Taittinger to establish a new veteran movement called the Young Patriots (Jeunesses Patriotes). ${ }^{55}$ At the moment of its creation, the movement did not have a

48 Prelom yr I No 19, 24 May 1934, picture on page 2.

49 Gervart 2013: 340-343.

50 The movement was established in 1889 as a reaction of rightist intellectuals to the revision of the Dreyfus Affair. With the leadership of Provençal writer Charles Maurras, the movement created a complex construction intertwining the ideas of counter-revolutionary (monarchism and clericalism) and modern social thinkers (syndicalism and corporatism) and ushering in an ideological system which has been characterized in modern historiography as the precursor of fascism (Davies 2002: 79-110).

51 Weber 1962: 97-99, 115-117.

52 Gervart 2013: 348-356.

53 During the pre-war and war years, the leadership of the French Action vehemently criticized the pacifist attitude of the Socialist Party. According to the theory of neoroyalists, a conspiracy hid behind the socialists' pacifism officially based on international class solidarity, i.e. with their criticism of war propaganda and advocation of peace, socialists put themselves in the service of Germany in exchange for material compensation. A more far-reaching result of the French Action's propaganda was the equalization, among the wider population, of the notions of the leftist and the traitor - a spy in German service.

54 Weber 1962: 90-91, 94, 102-103.

55 Brown 2014: 193-194. 
clearly defined ideology, but acted as the protector of the order from communism, revolutionary socialism, anarchism and masonry. ${ }^{56}$ Taittinger was a monarchist - Bonapartist, and maintained close links with the French Action, from whose ideology and political practice he took over terror as a means of confrontation with political opponents and the advocation of a sweeping social reform based on class cooperation. The membership of the movement was organized upon the principle of a militia with centuriae (hundreds) as the main operational group - unit. Centuriae members were uniformed (blue blouses and blue berets) and armed with poles. According to police estimates, the movement had over 90,000 members. During 1925 and 1926, the Young Patriots held over 180 rallies, criticizing the lenience of the Cartel of the Left towards leftist extremists and organizing the marches of their militia through places known as leftists strongholds. Frequent conflicts with leftist activists, leaving eight members of the movement dead, would often erupt at rallies and marches. In these street skirmishes the Young Patriots often had the support and assistance of the party militia of the French Action, the so-called King's Camelot's. The joint struggle and suffering in the clashes with leftist activists brought the Young Patriots even closer to the neoroyalists. ${ }^{57}$

Looking up to the Young Patriots, in 1927 business magnate François Coty and veteran captain Maurice d'Hartoy established the veteran movement called the Cross of Fire (Croixde-Feu). François Coty was the founder, chief financer and main ideologist of the movement. His ambition was to have the Cross of Fire become an ideologically precisely defined movement, set apart from the hitherto veteran political organizations. Just like Taittinger, Coty was close to the French Action (he was a monarchist and Bonapartist, and until 1926 one of the main financiers of the neoroyalist movement), and thus the ideology of the Cross of Fire relied largely on the ideas of Charles Maurras. Aiming to popularize his movement among veterans, Coty placed at the head of the Cross of Fire the decorated veteran, colonel, count François de La Rocque. Being one of the most ambitious and skillful politicians of the French right-wing, in 1929 colonel de La Rocque managed to suppress Coty from the movement's leadership and to position himself, until 1931, as an undisputed authority for members. ${ }^{58}$

After leaving the Cross of Fire in 1929 François Coty established a new veteran movement called the French Solidarity (Solidarité Française) led by captain Jean Renaud. ${ }^{59}$ Through high-circulation papers in his ownership such as Le Figaro and L'Ami du peuple, Coty propagated his vision of paternalistic capitalism and aggressive anti-communism, which he devised during his engagement in the Cross of Fire ${ }^{60}$ This concept attracted to the movement industrial workers from the Parisian suburbs and around 2000 veterans who made up the movement's party militia. ${ }^{61}$

In the early 1930s France felt the first effects of the global economic crisis, which reflected particularly on the veteran population. Until 1932, as industrial production contracted, many veterans remained jobless. The collapse of the German economy halted German reparations and veteran and disability pensions were slashed. The economic crisis

\footnotetext{
Warner 1981: 312.

Weber 1962: 160, 162, 300.

Warner 1981: 312.

Brown 2014: 193-194.

Hamilton 1978: 248.

Kedward 1969: 78-79.
} 
and the plummeting standard of living were accompanied by a series of financial affairs which involved high officials of the Republic. Veteran movements launched demonstrations across France, protesting against unemployment and pension cuts. Uncertainties were further fuelled in early 1933, when the NSDAP seized power in Germany. The French Action and its leaders availed of the dissatisfaction of veterans who joined the demonstrations and protest marches of neoroyalists, where the economic and foreign policy of the Republican regime was criticized. ${ }^{62}$

In December 1933 newspapers disclosed an affair concerning illegal speculation of bonds of the Bayonne port. Emigrant and Ukrainian Jew Serge Alexandre Stavisky, who was already suspected of numerous financial embezzlements, was in the midst of the affair. ${ }^{63}$ By bribing judicial and administrative authorities, Stavisky had already avoided a trial several times, but his machination with Bayonne bonds financially ruined a great number of shareholders and it became known as the Stavisky Affair. ${ }^{64}$ This event triggered a series of demonstrations led by the French Action, with the Camelot's entering into physical clashes with the police. The demonstrations were joined by members of the veteran organizations Young Patriots, Cross of Fire and French Solidarity, as well as many revolted citizens who were not members of these organizations. The demonstrations which protracted into several days were exceptionally violent. The culmination was the conflict on the Place de la Concorde on 6 February 1934. That day, upon the invitation of their leader Charles Maurras, several thousand members of the party militia of the French Action attacked the police cordon which secured the Place de la Concorde, which turned out into an all-day conflict. The activists of the French Action were joined by the Young Patriots, Cross of Fire, French Solidarity and several other smaller veteran organizations. By resorting to firearms, by midnight the police managed to push back the Camelot's and veterans from the Place de la Concorde. Fourteen demonstrators were killed and several hundreds of them were lightly or severely wounded. ${ }^{65}$

The Camelot's' conduct during the 6 February event gave the French Action the reputation of the most uncompromising organization among the French rightists and attracted to it the majority ${ }^{66}$ of veteran organizations. ${ }^{67}$ Close links between the neoroyalists and veteran movements were formalized with the establishment of the National Front in May 1935. ${ }^{68}$ The Young Patriots, French Solidarity and several other smaller veteran organizations joined the National Front, which was devised as a supra-party platform for the coordination of rightist forces. ${ }^{69}$ Although the French Action did not formally join the National Front, it

\footnotetext{
Hamilton 1978: 243-245.

Brown 2014: 194-198.

Weber 1962: 319-321.

Weber 1962: 333-338.

Suspecting that his movement would be ideologically and organizationally absorbed by the French Action, François de La Rocque, whose ambition was to maintain an independent political role, aimed to keep his movement outside these trends. In this endeavour, de La Rocque led the Cross of Fire movement towards its transformation into a civic party which would be an acceptable political partner to the leading structures of the Republic. In 1935, de La Rocque consistently implemented the legal regulation on the dissolution of the movement militia and in 1936 transformed his organization into the political party called the Socialist Party of France (Warner 1981: 312-315).

67 Weber 1962: 347.

68 Brown 2014: 204.

69 Weber 1962: 350-351.
} 
supported its actions and ideologically shaped its political programme. The organization was formally headed by Bonapartist Charles Trauchee, but many contemporaries considered Charles Maurras the true leader of the Front. With the creation of the National Front, the ideological influence of the neoroyalist movement on veteran organizations became stronger. They embraced Maurras' theory of democracy and parliamentarism from the ideological discourse of neoroyalism, as well as the vision of a class-corporate reorganization of the state and the political practice of using terror in the struggle against political opponents.

One of the main characteristics of the political movements of war veterans in France was their organizational and ideological disunity. Several movements and leaders tried, by applying various methods, to impose themselves as the exclusive representatives of a single numerous social group. The ideological scope of veteran movements was exceptionally broad, but could be summed up in several points, such as anti-communism, clericalism of a far-reaching social reform towards an agreement between labour and capital based on class solidarity, and the request for maintaining the foreign policy position of France as the main military continental force. ${ }^{70}$ Another specificum was the inclination of veteran movements to rely, in defining their ideological views, on the ideological concepts of the French Action with which everyone maintained close links and cooperation.

\subsection{Veterans in AFY}

The analysis of programme articles published in the AFY's main gazette Prelom shows that the ideology and political practice of French veteran movements exerted a strong influence on the creation of AFY's ideology and political practice. Prelom kept a close eye on the political circumstances in France and the participation of French veteran movements in political life. In the articles such as What is New in the West,${ }^{71}$ Fighters in Fire, ${ }^{72}$ Ideas, ${ }^{73}$ Speech of Comrade Stane Vidmar ${ }^{74}$ and French Fighters, ${ }^{75}$ the authors praised the French veteran movements Cross of Fire, Young Patriots and French Solidarity and their patriotism and decisiveness in the struggle for the interests of the French state and nation. Similarly to the political movements of French veterans, in creating their own ideology, the ideologists of AFY started from the criticism of the contemporary political elite and its negligent treatment of the victory of the national armed forces in World War I, which brought into question the concept of national security. By defining the reasons inciting them to act as an organized political group, in their articles such as At the Turning Point, ${ }^{76}$ Volunteer Action ${ }^{77}$ and The Rally of AFY Delegates from the Drava Banovina ${ }^{78}$ the ideologists of AFY stated that former soldiers, as a group who gave the greatest contribution to the creation of the Yugoslav state, were socially

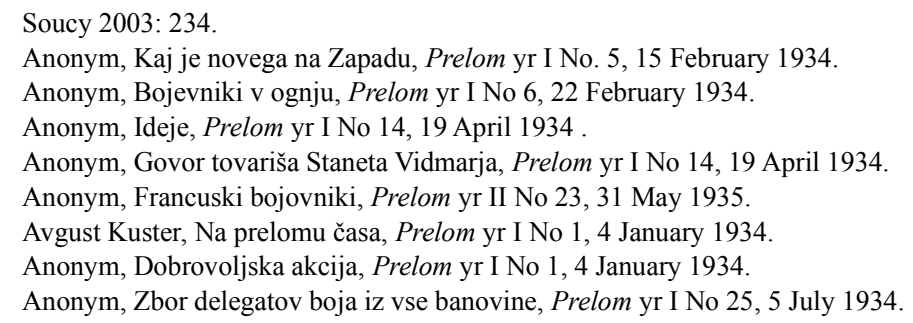


and politically marginalized. Not feeling the need to be recognized as an independent political factor, former soldiers passively observed professional politicians who, due to their incapacity and driven by personal ambitions, brought into question the results of all efforts and sacrifices embedded in the creation of the Yugoslav state. Former soldiers could no longer tolerate such a situation and AFY was the expression of their wish to get actively involved in the country's political life. As in the case of French veteran movements, the ideologists of AFY saw a great danger in the new strengthening of Germany, which resulted in the collapse of the European order based on the Treaty of Versailles. The concern of AFY ideologists was most explicitly presented in the articles such as Foreign Policy in the New Times, ${ }^{79}$ The Saar Plebiscite ${ }^{80}$ and Habsburg Demons ${ }^{81}$, whose authors warned the public of the revisionist tendencies in Europe backed by national-socialistic Germany (the annexation of the Saar region and preparations for the Anschluss) and appealed with the leading structures to undertake steps and preclude the imminent war.

\subsection{Criticism of corruption}

Just like French veterans, the ideologists of AFY strongly opposed the leading structures which, in their view, jeopardized national security through unconscientious pursuit of state affairs. The heritage of the OYN theory of integrationist Yugoslavism and the attempts of regime politicians to transform AFY into a platform of the leading party turned the movement against the regime Yugoslav National Party (YNP) in which, according to the estimates of AFY ideologists, the politicians from the pre-6 January era had the main say these politicians, for the sake of their personal ambitions, insincerely adopted the policy of state and national unity. As in the French case, the regime was criticized from the position of struggle against corruption. In the articles such as Membership in Defence of the People, ${ }^{82}$ Why Do You Cry Loudly Against Corruption ${ }^{83}$ and Against Corruption ${ }^{84}$, the authors criticized the YNP regime which, by tolerating corruption among its ranks, jeopardized the existence of the ordinary man and contributed to the loss of trust in the government and its institutions among the wider population. The rulers who practiced or disguised corruption were presented as "the gravediggers of the state", endangering with their unconscientious policy the defence potential of the state and its foreign policy position. The ideologists of AFY welcomed the fall of the YNP regime, whose rule they characterized "as the government of violence, corruption and protectionism under the guise of false Yugoslavism. ${ }^{\text {" } 85}$

\subsection{Peasantry in the ideology of AFY}

The ideologists of AFY made a sharp turn in the field of social policy compared to

\footnotetext{
Lojze Kuhar, Zunaja politika v novi dobi, Prelom yr I No 1, 4 January 1934.

Anonym, Plebiscit v Posarju, Prelom yr II No 4, 24 January 1935.

Anonym, Habzburški demoni, Prelom yr II No 29, 1 August 1935.

Anonym, Ljudstvo in narodna bramba, Prelom yr I No 8, 8 March 1934.

Anonym, Ve zakaj vedno grmite zoper korupcijo, Prelom yr I No 17, 10 May 1934.

Anonym, Zoper korupcijo, Prelom yr I No 26, 12 July 1934.

Anonym, Dve leti, Prelom yr II No 36, 14 December 1935.
} 
OYN. Former OYN members, gathered within the new movement, correctly assessed that the OYN propaganda, which aimed to win over the urban worker population and which treated the village as a preserve of tribal separatism, disabled the advance of the idea of integrationist Yugoslavism among the ranks of the agrarian population. Aiming to make agrarian workers accept their ideology (these workers made up over $80 \%$ of the population of the Kingdom of Yugoslavia), bojevniks launched aggressive propaganda in order to win over Slovenian peasantry for the objectives of their movement. The re-orientation of the propaganda activity of Slovenian Yugoslav integrationalists was certainly supported by the fact that a large portion of the AFY membership came from the ranks of the Slovenian Agricultural Party (SAP), which had a strong influence on the well-developed and widespread cooperative movement in the territory of the Drava Banovina. In addition, bojevniks had the ambition to take over cooperatives and agricultural credit bureaus formed in the 1920s by the dissolved SPP. In the articles such as Peasants - Fighters in the Foreground, ${ }^{86}$ The Founding Meeting of the Banovina Board of AFY ${ }^{87}$ Peasants Fighting for their Rights, ${ }^{88}$ and Struggle for Justice, ${ }^{89}$ the ideologists of AFY emphasized that the peasantry gave the strongest contribution to the war efforts aimed at the creation and defence of the Yugoslav state. Although, in percentage terms, peasants - soldiers contributed the most to the creation of the Yugoslav state, they and their interests were neglected due to the interests of parties which remembered the Yugoslav village only before elections. In line with this, the ideologists of AFY emphasized that the village, its economic interests and cultural needs had to become the foundation of state policy and economy. ${ }^{90}$ The theses put forward by AFY ideologists about the key role of the Slovenian peasantry in the struggle for the creation of the Yugoslav state were highly questionable. In the pre-war period in Slovenia, the Yugoslav idea was accepted only by a narrow stratum of the city intelligentsia who belonged to the pre-war Liberal Party, and university and secondary school students gathered around several papers which promoted the ideas of the Yugoslav Nationalistic Youth (YNY). Almost all Slovenians - volunteers in the army of the Kingdom of Serbia and fighters in Pivko's battalion in Italy came from the ranks of the liberal intelligentsia and youth circles that advocated the YNY ideas. In the pre-war and war period, Slovenian peasantry was under the dominant influence of the clerical SPP which until 1918 pursued a loyalist policy towards the Habsburg Monarchy. The idea of integrationist Yugoslavism in Slovenia gained wider support only after 1918, when the borders of the new state jeopardized the ambitions of Italy and Austria. The loss of Carinthia, Istria, Gorica, Trieste and the Slovenian littoral, the provinces with a significant portion of the Slovenian population, in favour of Austria and Italy influenced a part of the agrarian population of Slovenia to embrace the theory of integrationist Yugoslavism. The attempts of the AFY leadership to construct, regardless of facts, the image of a Slovenian peasant warrior as the main cultural, economic and military actor in the Yugoslav state reflect some ideological elements of contemporary French veteran movements which glorified the French peasantry

\footnotetext{
Ferdinand Kafol, Kmetje boric na plan, Prelom yr I No 2, 18 January 1934.

Anonym, Ustanovna seja Banovinskog odbora Boja, Prelom yr I No 3, 1 February 1934.

Anonym, Kmetskim borcem za svoje pravice, Prelom yr I No 4, 8 February 1934.

Anonym, Boj za staro pravdo, Prelom yr II No 10, 7 March 1935.

Anonym, Temeljna načela, Prelom yr I No 48, 13 December 1934.
} 
as the main bearer of war efforts and the key protagonist of the victory in the Great War. This ideological concept was to enable the AFY leadership to gain influence over the welldeveloped cooperative movement in the Drava Banovina. With this objective in mind, bojevniks resisted the attempts of the regime YNP to take Slovenian cooperatives to the Central Union of Agricultural Cooperatives, stating that cooperatives should be depoliticized and left in their authentic organizational forms. ${ }^{91}$

\subsection{Clericalism}

The attempts of AFY ideologists to attract to their movement Slovenian peasantry that was under a strong influence of the Roman Catholic Church resulted in a much more tolerant attitude of Slovenian Yugoslav integrationalists towards religion. ${ }^{92}$ In principle, similarly to OYN members, AFY ideologists emphasized that the interference of religion with politics obstructed the creation of a single Yugoslav people, but aimed to mitigate the criticism claiming that the instrumentalisation of religion for political purposes was the political practice of the pre- 6 January parties without a future in the Kingdom of Yugoslavia. Just like their OYN predecessors, bojevniks had discussions with leaders of the dissolved SPP and their gazette Slovenija. ${ }^{93}$ The alleviation of the anti-clerical attitude typical of the OYN movement in the 1920 s was certainly also inspired by the attitudes of French veteran movements, which praised in their gazettes "the union of the throne and altar", strongly criticized the sacrilegious methods of extremists from the French Revolution and presented the warriors of the counter-revolutionary Vendée as an ideal of the military spirit. ${ }^{94}$ In public appearances of the AFY leadership and articles of the movement's gazettes, there was a frequent use of analogies from Christian holy scriptures. Thus, the programme articles of AFY gazettes read that "God Saves Yugoslavia" (as otherwise it would have collapsed a long time before due to poor administration and corruption), ${ }^{95}$ while the introduction of the 6-January dictatorship and the dissolution of old parties were compared with Jesus' expulsion of merchants from the temple ${ }^{96}$ and AFY's struggle for its political ideas with the temptations of Christ. ${ }^{97}$ In addition to using Biblical analogies in their propaganda, in some of their programme articles AFY ideologists expressed their readiness to cooperate with the Roman Catholic Church, which was an absolute precedent in the hitherto attitudes of the proponents of integrationist Yugoslavism towards the role of religion in the political life of the Yugoslav state. Avgust Kuster went the farthest in this regard. In his article At the Crucial Time, he analyzed the causes of the crisis in Yugoslav society and reached the conclusion

\footnotetext{
Anonym, Poenotenje našega zadružništva, Prelom yr I No 35, 13 September 1934.

The population of Slovenia was under a strong influence of the clergy of the Roman Catholic Church which in the late 1860s headed the struggle for the political and ethnic emancipation of the Slovenians in the Habsburg Monarchy (Ekmečić 1989: 161, 521). The dominant position of the clergy in Slovenia's political life doubtless influenced the ideologists of AFY (unlike the predecessors from OYN) to avoid open confrontation with the Roman Catholic clergy.

93 Anonym, Odgovor napadalcem, Prelom yr II No 28, 19 July 1935.

94 Koller 2006: 258; Davies 2002: 89.

95 Anonym, Govor tovariša Dimitrija Ljotića, Prelom yr II No 34, 25 October 1935.

Anonym, Govor tovariša Tureta Šturma, Prelom yr I No 14, 19 April 1934.

Avgust Kuster, Velika noć, Prelom yr II No 16, 18 April 1935.
} 
that one of the key triggers of the social crisis was a general decline of morality and that, in addition to the struggle for the political and economic revival of the state, it was necessary to launch the struggle for the moral and spiritual revival of the people in union with the Church. ${ }^{98}$ The struggle for moral revival based on Christian spiritual values was one of the greatest innovations introduced by AFY ideologists into the ideological discourse of the right-wing with integrationist Yugoslav orientation. This innovation became one of the fundamentals of the ideology of YNM Zbor, which gathered and led the forces of integrationist Yugoslavism in the second half of the 1930s.

\subsection{Concept of state organization}

Just like the ideologists of French veteran movements, in their programme articles about the potential type of state organization, AFY ideologists examined a wide range of ideas - from the advocation of dictatorship ${ }^{99}$ to the glorification of democracy as a form of state organization underpinning the Yugoslav state. ${ }^{100}$ The attitude of AFY ideologists towards a potential economic model which should be implemented in the Yugoslav state was somewhat more concrete, but still not precisely defined in the articles such as Fighters Soldiers in $A F Y^{101}$ and Prism ${ }^{102}$, where the authors criticized liberal capitalism as an unsustainable system which encouraged class conflicts in Yugoslav society. On the other hand, AFY ideologists were not unanimous as to the alternative to liberal capitalism. The solutions proposed ranged from state interventionism upon the model established by Roosevelt in the USA, ${ }^{103}$ through basing the economic policy on the postulates of the cooperative movement, to the introduction of corporatism shaped upon the Italian model. ${ }^{104}$ The ideological ambiguity and absence of a precisely defined political programme prompted the AFY ideologists to take over, similarly to French veteran movements, some ideas from the ideologically close but better grounded movements. This tendency was visible already in May 1934, when a senior official of the Yugoslav Action Ivo Malinar appeared at the rally of bojevniks in Celje. As a representative of the ideologically related movement, Malinar put forward some ideological concepts of his organization among Slovenian bojevniks. ${ }^{105}$ After the rally in Celje, AFY's main gazette Prelom began to publish programme articles from the gazettes of other Yugoslav integrationist movements - Ljotić's Otadžbina, ${ }^{106}$ Parežanin's Zbor ${ }^{107}$ and Mojić's Buđenje. ${ }^{108}$ The AFY leadership praised with particular zeal the political ideas expressed in articles of the Otadžbina paper, which they qualified as the closest to the main ideological tenets of the movement. During the meetings

\footnotetext{
Avgust Kuster, Na prelomu časa, Prelom yr I No 1, 4 January 1934.

Anonym, Ali demokracija res umira, Prelom yr I No 9, 15 March 1934.

Anonym, Za demokracijo ili zoper njo, Prelom yr I No 11, 29 March 1934.

Anonym, Borci bojevniki in BOJ, Prelom yr I No 22, 14 June 1934.

Anonym, Prizma, Prelom yr II No 22, 23 May 1935.

Anonym, Zakaj je Rozvelt zmagal, Prelom yr I No 48, 13 December 1934.

Anonym, Celjski zbor, Prelom yr I No 18, 17 May 1934.

Anonym, Celjski zbor, Prelom yr I No 18, 17 May 1934.

Dimitrije Ljotić, Kvisku srca, Prelom yr I No 27, 19 July 1934.

Anonym, Nesebičnost, Prelom yr I No 33, 30 August 1934.

Anonym, Kaj hoće ljudstvo, Prelom yr I No 29, 2 August 1934.
} 
of the leadership of Yugoslav integrationist political groups in Belgrade and Pale in the spring and summer of 1934, AFY leaders Vladislav Fabijančić and Avgust Kuster met Dimitrije Ljotić, who left a strong impression on them. ${ }^{109}$ Avgust Kuster, the founder and prominent ideologist of AFY, emphasized that Ljotić was a multi-decorated volunteer from the Balkan Wars and World War I, as well as a political theoretician and cooperative activist, but primarily a soldier - veteran, who, as such, enjoyed the sympathies of the AFY leadership. ${ }^{110}$ After the establishment of the direct link with Ljotić's political group, numerous reflections of ideological precepts arising from the circle of the Otadžbina paper appeared in AFY's Prelom. In contrast to the earlier ambivalence towards the form of government and economic organization, as of the autumn of 1934, the AFY leadership began to express a clear attitude deriving from the ideas of Dimitrije Ljotić and the group gathered around Otadžbina. Judging by the articles such as Fighters Soldiers in $A F Y^{111}$ and Prism $^{112}$, it is possible to conclude that AFY ideologists fully embraced the criticism of parliamentary democracy and liberal capitalism based on the ideological precepts that Ljotic took over from the French Action. The article About the Class Parliament ${ }^{113}$ - in which an anonymous author propagated the transformation of the national assembly from a political into a professional representative body by granting the right to MP candidature to cooperatives, cultural and professional associations - shows even more explicitly the adoption of political ideas devised by Dimitrije Ljotić. The above examples clearly indicate that, in relation to AFY, Ljotić's political group had the same function which the French Action played for French veteran movements. The ideological alignment of AFY and Ljotić's political group culminated in the adoption of the joint political programme encapsulated in the text The Basic Principles, adopted simultaneously by the Yugoslav Action and the Small Zbor of Ratko Parežanin. In the articles The Basic Principles ${ }^{114}$ and The 1935 Year of Our Talk ${ }^{115}$, AFY ideologists presented the alignment of the programmes of Yugoslav integrationist right-wing movements as a new chapter in the work of AFY and announced even closer links among Yugoslav integrationist forces in the near future.

The chance for an even closer cooperation appeared in the spring of 1935 when the parliamentary elections were called. The decision of the AFY membership to support Ljotić's list brought about turmoil within the movement. The joint electoral appearance of Yugoslav integrationist groups was to presage their fusion into a single political movement. Some AFY members who did not regard benevolently the adoption of the ideological precepts of Ljotić's political group gathered around Stane Vidmar and opposed the leadership's decision to participate in the elections on Ljotić's list. Formulating the attitudes of disaffected members, Vidmar stood out against this decision, requesting from AFY to preserve its political autonomy and accusing the leadership of having departed from the original ideas of AFY with the adoption of the joint programme with Ljotićs group. After

\footnotetext{
Parežanin 2001: 47-48.

Avgust Kuster, Zakaj v listo tovariša Ljotića, Prelom yr II No 14, 4 April 1935.

Anonym, Borci bojevniki in BOJ, Prelom yr I No 22, 14 June 1934.

Anonym, Prizma, Prelom yr II No 22, 23 May 1935.

Anonym, O stanovskome parlamentu, Prelom yr II No 33, 3. October 1935.

Anonym, Temeljna načela, Prelom yr I No 48, 13 December 1934.

Anonym, 1935 leto naše besede, Prelom yr I No 50, 27 December 1934.
} 
backdoor strifes within the movement, Vidmar and his followers remained a minority, and most of them left the movement. This rift largely weakened AFY and inhibited it from implementing the election campaign. Thus, Dimitrije Ljotić's list won merely 2500 votes at the parliamentary elections in the Drava Banovina. ${ }^{116}$ Discouraged with the results of the elections, prominent members of AFY such as Vladislav Fabijančić and Avgust Kuster handed in their resignations and left political life. ${ }^{117}$ The remaining members led by Artur Sturm ${ }^{118}$ continued with their political engagement merging into YNM Zbor ${ }^{119}$ which was constituted as a single political movement after the 5 May elections.

\section{Conclusion}

As it was imprecisely defined and unoriginal in ideological terms, the AFY movement did not give a particularly great contribution to the formation of the ideological conception of YNM Zbor. In addition, the former bojevniks who after 1935 continued with their political engagement within the county board of YNM Zbor of the Drava Banovina brought to this movement few but fanatic members, who did not shy away from resorting to terror in the struggle with their political opponents. Exposed to constant pressure by the clerical Slovenian People's Party (which after the establishment of the Yugoslav Radical Union - YRU regime in 1935 gained monopoly in the political scene of the Drava Banovina), a traditional opponent of Yugoslav integrationist forces, the former bojevniks

116 Stefanović 1984: 44.

117 Gligorijević 1965: 74-77.

118 Born on 10 December 1894 in Split (his father was a Slovenian from Maribor - as an Austro-Hungarian civil servant, he happened to be on duty in this town). He was a soldier by profession. His engagement in World War I is not known. He was one of the founders and ideologists of AFY. Upon the creation of YNM Zbor in October 1934, he became one of the most reputable leaders of the movement in the Drava Banovina (Slovenia). At the parliamentary elections in 1935, Sturm was a candidate in the list of YNM Zbor for the Kamnik county. In 1935-1938 he was the secretary of the consortium of the Otadžbina paper and coordinator of the youth organization YNM Zbor for the Drava Banovina. After the April war he fled to Belgrade and joined the Serbian Volunteer Corps (SVC, Serbian SDK). After the capitulation of Italy in 1943 Šturm was sent to Ljubljana as an officer for liaison between SVC and the Slovenian Home Guard of general Leon Rupnik. Although there are no direct data about this, it is obvious that Šturm's engagement in Slovenia in 1943-1944 largely contributed to the creation and implementation of Ljotić's plan about the concentration of all anti-communist forces in Slovenia, which came into effect in late 1944 and early 1945. Upon the arrival of SVC forces to the Slovenian littoral, Šturm was the officer for liaison between the Zbor units and the German headquarters of general Odilo Globočnik in Trieste. There is no information about the destiny of Artur Šturm after the debacle of the anti-communist forces in Slovenia. It is only known that he emigrated (AB, Fund of Ljotićs organization Zbor, box no. 6, document: note about A. Sturm; AB, Fund of Ljotić's organization Zbor, box no. 6, document: National Candidate List for the elections of deputies for the National Assembly on 5 May 1935).

119 YNM Zbor was created after the Marseille assassination (9 October 1934) through the fusion of AFY, the Yugoslav Action and political groups gathered around the papers Otadžbina, Zbor and Buđenje. Under the leadership of Dimitrije Ljotić, the president and the main ideologist of the movement, a single ideological construction was created, relying on versatile ideological concepts (clericalism, anti-communism and antiSemitism) of the already established European fascist movements and some of Ljotić's own ideas (the concept of a cooperative state). For more information about the activity of YNM Zbor in the inter-war and war period see: Gligorijević 1963a, Gligorijević 1965, Dragosavljević 2013, Dragosavljević 2018: 369-580, Parežanin 2001, Propadović 1990, Payne 1995: 325-326, Stefanović 1984. 
radicalized their political methods, following in the footsteps of Slovenian OYN members from the 1920s. ${ }^{120}$ According to the instructions of Anton Korošec, the minister of interior and SPP leader, the local authorities in the Drava Banovina banned political rallies and conferences of YNM Zbor, dismissed prominent members of the movement from state service and arrested Zbor activists in order to impede pre-election activities. Revolted with these actions of the local authorities, Artur Šturm and his nine followers planned to carry out the assassination of Anton Korošec and Prime Minister Milan Stojadinović in 1938 during their joint visit to Ljubljana. Owing to intelligence information of the Ljubljana police, Sturm and his associates were arrested in the phase of planning the assassination and were delivered to the State Protection Court in June 1938. After a two-month investigation, Sturm and his associates were released due to the absence of evidence. ${ }^{121}$ The foiled assassination and the months-long custody entrenched the reputation of Zbor members from the Drava Banovina as the most uncompromising followers of the movement's ideology.

The process of shaping AFY's ideology largely overlapped with the Yugoslav Action and other contemporary Yugoslav integrationist organizations. The nucleus of the movement arose from the relics of the once powerful OYN organization from the Drava Banovina (Slovenia), which is why the entire ideological legacy of former OYN was incorporated into the ideological discourse of the new movement. Despite numerous ideological links between OYN and AFY, the new movement was a singular attempt of having a veteran organization act as an independent factor in the political scene of the Kingdom of Yugoslavia, relying on its own political programme. The idea of the AFY leadership to gather war veterans and their numerous associations within an independent political movement was doubtless inspired by the model of French veteran movements which in the late 1920s and early 1930s became a serious factor in French politics. An important factor was also the specific geostrategic position of the Drava Banovina as the farthest north-western border of the Yugoslav territory which suffered two-fold pressure from fascist Italy and Austrian Heimwehr. Jeopardized by the expansionist plans of fascist Italy and its ideological satellite - the Austrian Heimwehr, the AFY leadership tried, looking up to France as the hegemon of the Versaille order, to mobilize war veterans and their organizations as the element which showed most understanding of the security challenges facing the Yugoslav state. The changed internal political circumstances, i.e. the suspension of political freedoms under the regime of the monarchical dictatorship, brought about the alteration of the main ideological postulates of the OYN movement, which was also the case with the Yugoslav Action. The character of these alterations was greatly important as it foreshadowed radical political turnabouts in the ideological development of the Yugoslav integrationist movements of the radical right-wing. In the modified interpretation of the OYN theory of integrationist Yugoslavism by AFY ideologists, the attitude that the suppression of cultural-political traditions of Yugoslav tribes had a long-term negative effect on their national and cultural-political unification appeared for the first time. Such a critical attitude towards the rigid centralistic policy was later developed further in the ideology of

\footnotetext{
120 ASAF, Inventory No 17, box No 21, folder No 4, document: Two letters by Dimitrije V. Ljotić to the Minister of the Interior Monsignor Anton Korosec.

121 AY, fund No 37, folder No 21.
} 
YNM Zbor. At the same time, in their public appearances, the AFY leaders began to criticize for the first time the regime Yugoslav integrationist policy which, in their opinion, was of an exclusively conjunctural character and was, as such, a channel through which the pre-6 January political elite would return to the political scene. Reflecting the model of French veteran movements, the fierce criticism of the leaders of the YNP regime - manly through accusations of political opportunism (conjunctural Yugoslavism) and corruption - was the pattern for YNM Zbor to pursue the propaganda struggle against the regime of the Yugoslav Radical Union. The radical mitigation of the anti-clerical rhetoric was the element in which the ideological construct of AFY departed the most from the ideological precepts of OYN. In the ideology of Yugoslav integrationist movements of the radical right-wing, the stance that the church could be a constructive element in Yugoslav unification appeared for the first time in the ideological construct of AFY. Unlike their predecessors from OYN and contemporaries from the Yugoslav Action, the ideologists of AFY acknowledged the Roman Catholic Church as an important factor in the political life of the Drava Banovina (Slovenia). The AFY leadership's view of Christianity and its positive role in Yugoslav unification was incorporated and developed further in the ideological construct of YNM Zbor in the second half of the 1930s.

In general, organized upon the model of French veteran movements, AFY experienced a similar destiny. Due to the lack of intellectual and organizational capacities of its leadership, the movement did not acquire a coherent ideological framework and failed to position itself as a relevant political factor in the political scene of the Kingdom of Yugoslavia. Just like its French models, it sought an exit in the cooperation with ideologically better structured forces of similar ideological provenance. Placing itself from its very beginnings in 1934 under the ideological patronage of the group gathered around the Otadžbina paper and Dimitrije Ljotić, AFY managed to transcend local politics gaining the chance to develop its original ideological concepts within the ideological construct of YNM Zbor.

\section{REFERENCES:}

Archives:

$\mathrm{AB}$ - Archives of Belgrade (Fund of Ljotić's organization Zbor)

ASAF - Archives of the Serbian Armed Forces (Inventory No 17)

AY - Archives of Yugoslavia (Funds 37, 38)

ARS - Archives of the Republic of Slovenia (SI AS 1931, 935-600-12)

Periodicals:

Prelom paper (Ljubljana)

References:

Anatoličić, G. 'Marušić Drago', in: M. Pavlović (ed.), Senatori Kraljevine Jugoslavije: Biografski leksikon, Beograd: ISI, 2016, 195-197.

Avakumović, I. 'Yugoslavia's Fascist Movements', in: P. F. Sugar (ed.), Native Fascism in the Successor States, Santa Barbara: ABC-CLIO, 1971, 135-145.

Bakić, J. Ideologije Jugoslovenstva između srpskog i hrvatskog nacionalizma 1918-1941, Zrenjanin: Gradska narodna biblioteka „Žarko Zrenjanin”, 2004. 
Bartulović, N. Od Revolucionarne omladine do Orjune: Istorijat jugoslovenskog omladinskog pokreta, Split: ORJUNA, 1925.

Bošković, I. Orjuna: Ideologija i književnost, Zagreb: Sveučilišna naklada, 2006.

Brown, F. The Embrace of Unreason: France 1914-1940, New York: Alfred A. Knopf, 2014.

Čop, R. ORJUNA - prototip politične organizacije, diplomski rad odbranjen na Univerzitetu društvenih nauka u Ljubljani 2006.

Cvijić, J. Jedinstvo i psihički tipovi dinarskih Južnih Slovena, Beograd: Junior, 1999.

Davies, P. The Extreme Right in France, 1789 to the Present: From de Maistre to Le Pen, New York: Routledge 2002.

Devavari, Z. 'Violence as the Weapon of Political Parties. The Operation of ORJUNA and SRNAO in Vojvodina (1922-1924)', Istraživanja: Journal of Historical Researches, 28, 2017, 147-168.

Đorđević, M. 'Organizacija jugoslovenskih nacionalista (ORJUNA)', NSPM, 12, 2006, 187-219.

Dragosavljević, V. 'Ideološki uticaji evropskog fašizma na JNP Zbor (1934-1940)', Istraživanje mladih saradnika Instituta za noviju istoriju Srbije: Istorijska tribina, 2013, 93-109.

Dragosavljević, V. 'Influences of Italian Fascism on the Ideology and Political Practice of the Organisation of Yugoslav Nationalists (ORJUNA)', Serbian-Italian Relations: History and Modern Times - Belgrade, The Institute of History: Sapienza University of Rome, Research center CEMAS, 2015, 231-241.

Dragosavljević, V. Ideološki uticaji evropskog fašizma na jugointegralističke pokrete radikalne desnice u međuratnom periodu (1921-1941), doktorska disertacija odbranjena na Filozofskom fakuletu u Beogradu 2018.

Đurašković, S. Fascism in Central Europe: The Organisation of the Yugoslav Nationalists - ORJUNA (1921-1929), master rad odbranjen na Centralnoevropskom univerzitetu u Budimpešti 2007. (internet izdanje)

Ekmečić, M. Stvaranje Jugoslavije 1790 -1918 II, Beograd: Prosveta 1989.

Gervart, R. Horn Dž. Rat u miru: Paravojno nasilje u Evropi posle Prvog svetskog rata 1918-1923, Beograd: Arhipelag, 2013.

Gligorijević, B. 'Napad Ljotićevaca na student Tehničkog fakulteta i rasturanje Zbora', Istorijski glasnik, 2, 1963a, 52-81.

Gligorijević, B. 'Organizacija jugoslovenskih nacionalista (Orjuna)', Istorija XX veka: zbornik radova, 5, 1963b, 315-393.

Gligorijević, B. 'Osobenosti fašizma u Jugoslaviji dvadesetih godina', Marksistička misao, 3, 1986, $32-44$.

Gligorijević, B. 'Politički pokreti i grupe sa nacionalsocijalističkom ideologijom i njihova fuzija u Ljotićevom Zboru', Istorijski glasnik, 4, 1965, 35-82.

Gligorijević, B. Kominterna-jugoslovensko i srpsko pitanje, Beograd: ISI, 1992.

Grizogono, P. Savremena nacionalna pitanja, Split: ORJUNA, 1923.

Hamilton, A. Fašizam i intelektualci 1919-1945, Beograd: Vuk Karadžić, 1978.

Kedward, H. R. Fascism in Western Europe 1900-1945, New York: New York University Press, 1971.

Koller, C. 'French Revolution, The', in: C. Blamires (ed.), World Fascism: A Historical Encyclopedia, Oxford: Oxford University Press, 2006, 257-259.

Ković, M. 'Jovan Skerlić', in: M. Ković (ed.), Srbi 1903-1914: Istorija ideja, Beograd: CLIO, 2015, 536-587.

Malin, F. Jugoslovenstvo kroz istoriju: Fragmenti, Split: ORJUNA, 1925.

Matković, H. Svetozar Pribićević i Samostalna demokratska stranka do šestojanuarske diktature, Zagreb: Izdavački servis „Liber”, 1972.

Parežanin, R. Drugi svetski rat i Dimitrije V. Ljotić, Beograd: Junior, 2001.

Payne, S. A History of Fascism 1914-1945, Wisconsin: University of Wisconsin Press, 1995. 
Pribićević, S. Izabrani politički spisi, Zagreb: Golden marketing, 2000.

Propadović, M. Dimitrije V. Ljotić, Zbor I KPJ 1935-1945, Nortempton: Iskra, 1990.

Soucy, R. 'French Fascism: The Second Wave 1933-1939', in: A. Kallis (ed.), The Fascism Reader, London: Routledge, 2003, 232-241.

Stefanović, M. Zbor Dimitrija Ljotića (1934-1945), Beograd: Narodna knjiga, 1984.

Šuštar, B. 'Ekonomska ORJUNA: Pokus gospodarske organizacije jugoslovanskih nacionalistov v 20ih letih tega stoletja', Kronika: Časopis za slovensko krajevno zgodovno, 36, 1989a, 144-146.

Šuštar, B. 'O razširjenosti Organizacije jugoslovanskih nacionalistov na Slovenskem do sredine leta 1924', Kronika: Časopis za slovensko krajevno zgodovno, 36, 1989b, 242-246.

Warner, G. 'France', in: S. Woolf (ed.), Fascism in Europe, London: Littlehampton Book Services Ltd, 1981, 307-328.

Weber, E. Action Francaise: Royalism and Reaction in Twentieth-Century France, Stanford: Stanford University Press, 1962.

\section{ВАСИЛИЈЕ ДРАГОСАВЉЕВИЋ}

Историјски институт, Београд

\section{БОРАЧКА ОРГАНИЗАЦИЈА ЈУГОСЛАВИЈЕ - БОЈ (1929-1935): ИДЕОЛОГИЈА-ПРАКАСА-ИСХОД}

\section{Резиме}

Рад има за циљ да изложи процес настанка - организационог и идеолошког уобличавања ветеранског покрета Борачка организација Југославије (БОЈ) и осветли његову улогу унутар миљеа југоинтегралистичких снага током прве половине 30-тих година XX века. Предмет посебне пажње биће идејне рецепције из идеолошких конструкција Организације југословенских националиста и савремених француских ветеранских покрета. Поред тога у раду су приказани и комплексни односи између БОЈ-а, шестојануарског режима и савремених идеолошки сродних политичких група, као и улога идејних концепција БОЈ-а у креирању идеологије Југословенског народног покрета Збор.

Кључне речи: Борачка организација Југославије, Организација југословенских националиста, интегрално југословенство, клерикализам, ЈНП Збор. 